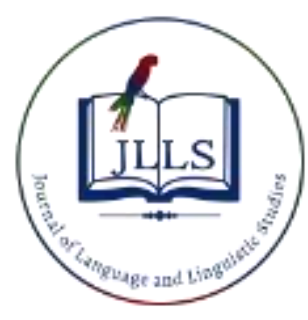

Available online at www.jlls.org

JOURNAL OF LANGUAGE AND LINGUISTIC STUDIES

ISSN: $1305-578 \mathrm{X}$

Journal of Language and Linguistic Studies, 16(2), 1032-1042; 2020

\title{
Language choice and identity: An investigation based on the comparison of language attitudes from two different localities
}

\begin{abstract}
Filiz Çetintaş Yıldırıma ${ }^{1}$
${ }^{a}$ Mersin University, Mersin, Turkey

\section{APA Citation:}

Çetintaş Yıldırım, F. (2020). The Language Choice and Identity: An Investigation Based on the Comparison of Language Attitudes from Two Different Localities. Journal of Language and Linguistic Studies, 16(2), 1032-1042.

Submission Date:14/02/2020

Acceptance Date:18/03/2020

Abstract

This current research tries to compare and contrast the language attitudes of Arabic-Turkish bilinguals from Mersin and Hatay cities located in the East Mediterranean Region of Anatolia. The quantitative results of the language attitude surveys conducted in the two cities by two different researchers (Çetintaş Yıldırım, 2019; Kocaoğlu, 2019) are compared, and qualitative conclusions which can be generalized to the population of Arabic-Turkish bilinguals are obtained. Two different but related themes (language choices and the sense of belonging to a social/cultural identity of the two participant groups) consist of the main focus. Four sets of questions for the identity theme and seven sets of questions for the language choice theme were determined from the surveys and the means of each group for every question were compared and interpreted. The comparison reveals that Arabic-Turkish bilinguals from Hatay interiorize Arabic language more than Arabic-Turkish bilinguals from Mersin. The first group is more inclined to use Arabic in their professional career and transfer it to the new generations.
\end{abstract}

(C) 2020 JLLS and Filiz Çetintaş Yıldırım - Published by JLLS.

Keywords: language choice; social/cultural identity; language attitudes; Arabic-Turkish bilingualism

\section{Introduction}

Reports and researches reveal that other than Turkish which is the official language, there are many minority languages spoken in Turkish Republic. Andrews (1989) classifies 41 minority languages in Turkey including Turkish sign language, (Northern and Southern varieties of) Arabic, Kurdish, Zazaki and Uzbek, and many others. Karahan (2005) lists 31 minority languages divided according to sociological demographic distributions like religious basis and language families of the minority languages (p. 1160). A survey held by KONDA (2017) sums up minority languages in Turkey as 15, basing the number to self-reports of different ethnic groups (p. 19). Of the third largest ethnic minority, which is consisted of Arabic-origin residents who are mostly settled in the South and South-Eastern Anatolia, citizens speak North Levantine Arabic which lacks a written a form. This Arabic variety has been orally transmitted from generation to generation, and for this reason, became an endangered minority language in Anatolia. Andrews reports the proportion of Arabic-Turkish Bilinguals (ATB) as

\footnotetext{
${ }^{1}$ Tel.: +90-324-361-0001

E-mail address: fcetintas@mersin.edu.tr
} 
$1.63 \%$, Karahan as $1,16 \%$ and KONDA as $1,38 \%$ of the whole population of Turkish Republic. What is more, as Turkish is seen as the prestigious language among speakers of this variety (Çetintaş Yıldırım, 2019 , p. 82 and Kocaoğlu, 2019, p. 114), code-mixing is very widespread during Arabic conversations in daily life. Most of the Arabic native words were replaced by Turkish loan words, and original Arabic words became incomprehensible to ATBs. The aspects mentioned above attract attentions of linguistic fieldworkers to the language attitudes of ATBs towards Arabic and Turkish.

\subsection{Literature review}

Language attitudes and their reflections to social behaviors are topics of investigation in most studies. Various approaches have been developed for clearly explaining what language attitude is and how it affects the social structures and tendencies. According to Agheyisi and Fishman (1970), language attitudes are dependent variables which are affected by time, speaker dynamics and language policies (p. 138-141). They are consisted of affective components, are learned via environmental experience and are enduring. So, they comprise positive relation to the actions or behaviors of speakers in a speech community. The reflections of all attitudes should be observed as a kind of particular behavior in the society. Cargile and Giles (1997) emphasize that studies on language attitudes give clues about "the ways in which listeners may be evaluatively predisposed to others who feature particular language behaviors...listeners react emotionally, as well as evaluatively, to differences in a speaker's accent and message." (p. 213). The evaluations - attitudes here - of speech communities can shape the way of thinking and course of action of a whole society. In a similar way, Liebscher and Dailey-O'Cain (2009) reports that language attitudes are dynamic states of affairs which cannot be retrieved easily because of their unfixed status in speaker mind (p. 217). Social interactions are the creators of attitudes which can be turned into certain ideologies that speakers involuntarily contribute or object to. Language attitudes studies mostly concentrate on evaluative responses of speakers which play a significant role on determining social behavior (Gawronski, 2007, p. 579). As Edwards (1999) states, "the variation found in speech-evaluation studies reflects social perceptions of the speakers of given varieties ...", and the occurrence of social perceptions is not random (p. 102). There are different frames for observing social evaluations including the two evaluational categories as "social status and solidarity". Thus, the power of language (varieties) over generating a sense of social identity is obvious and language attitude studies can shed a light on underlying mechanisms of social behavior.

This current study tries to reveal the differing language attitudes of native speakers in two different areas where North Levantine Arabic is spoken as mother tongue. The ATBs' language attitudes towards Arabic and Turkish were previously characterized by two different studies: in Mersin (Çetintaş Yıldırım, 2019) and in Hatay (Kocaoğlu, 2019). Some findings of these two studies are going to be compared in order to gain a deeper insight about how bilingual speakers from different geographical areas perceive their mother tongues and how their attitudes shape their sense of identity and their language choice.

The results will be useful to provide information about to what extend one language is considered as privileged over the other and how language choices are affected by the attitudes of ATBs. Preparatory to answer the questions, a few remarks on bilingualism and its effects on identity and language attitudes of other bilingual speakers (speakers of languages other than Arabic) in Turkish Republic should be stated.

\subsubsection{Bilingualism and identity}

Bilingualism and ethnic/social identity are two interrelated concepts which are strongly affected by governmental language policies and power relations among languages in question. As Çetinkaya (2017) remarks, different uses of languages and their varieties can shape both the social perceptions of individuals and the dispositions of societies. Every culture initiates a particular world view and every 
language represents a particular society. When this strict relationship is taken under investigation, it is seen that speech communities endeavor for the maintenance or consolidation of their ethnic identity through the use of their mother tongue. As social identity is a dynamic phenomenon, the absence of an accomplished identity is obvious and the effects of bilingualism on social identity have to be examined under the context which includes the connection of individualism and collectivism. The reason for this is that language acquisition can also be considered as a kind of indigenizing cultural features. Büyükkantarcioğlu (2006), similarly, emphasizes that not only individuals in a speech community but also subgroups and societies do possess identities (p. 62). By taking language, culture and power relations in the main focus, Weisman (2001) reports that there is a strong relationship between speaking the mother tongue and belonging to a cultural identity (p. 203-208). The preference of one language over the other can be seen as an indication of the bilingual speaker's opinion about his/her identity. Bilinguals not only speak two languages but also have the characteristics of two cultures, and one of the two cultures may be dominant over the other. This dominancy is most likely reflected by the preference of one language to socialize as it is in the sample of four Latina teachers. Latina teachers value Spanish language in their conversations with Latino students for confirming students' cultural identity. Choi (2003), similarly, concludes that Guaraní-Spanish speaking bilingual children see Guaraní language as the "symbol of Paraguayan language, tradition and identity" and have positive attitudes towards that language (p. 91). Yet, they place a premium on Spanish language, which has official dominancy over Guaraní, for they feel more comfortable expressing themselves in Spanish. The case Choi presents is a good example of confrontational positions that social sense of belonging and social dominancy are in. Mukhuba (2005) draws attention to the imbroglio in South African countries where English is adopted as the official language, but where there are conflicting views about the candidate of a second official language among the native languages spoken by different tribes. This problem can only arrive at a solution if there is a general consensus on which language is planned to be the second official language. Bangeni and Kapp (2007), in their study on shifting language attitudes in South Africa, emphasize that ideologies about language are not focused on languages alone; social situations, identity and power relations in societies are strictly tied to language attitudes (p. 258-266). For instance, language shifts occur in South African societies because of the intensive use of English in university environments. It seems that although bilingual language communities try to preserve their native languages to retain their ethnic identities, they value dominant official languages for daily communicational purposes, which initiates a future language shift.

\subsubsection{Language attitudes in Turkey}

As stated before, at least 15 languages are spoken in Turkish Republic, and speakers of these languages (most of them are bilinguals) possess different language attitudes towards their native languages and Turkish. Immigrants of English origin, living mostly in the Eastern region of Anatolia and consisting of elderly people, hold positive attitudes towards Turkish, but do not prefer speaking it in their daily lives. These speakers limit their interaction with Turkish habitants, so the consolidation process cannot be established. On the contrary, this results in a cultural discrimination process (Antonova-Ünlü \& Sağın Şimşek, 2016, p. 69-70). A similar research (Antonova-Ünlü et al, 2015) which was conducted on Russian immigrants in Turkey, differently, concludes that these speakers use both Russian and Turkish. They integrate themselves into Turkish culture, at the same time preserving their own cultural characteristics. Being proficient in both languages is important for their professional goals, so they also want their children to speak Russian and Turkish and try to transmit both languages from generation to generation, which brings acculturation with itself. Atsız Gökdağ (2011) reports that in Eastern Black Sea region, where there are four spoken minority languages and different cultures, speakers are adapted their ways of life to the host culture and do not consider themselves as having an independent social identity. Another study (Yalınkılıç \& Yağmur, 2014), conducted on Western 
Thracian Greek language speakers of Turkish origin, demonstrates that these speakers define their identity as Turkish and they mostly communicate in Turkish language. In addition, the sense of belonging to Turkish identity shows a fair amount of decrease among younger generation (aged between 15 and 30) according to statistical evidence. Younger generation looks with favor on Greek identity and indicates that Greek culture is an inseparable part of their self. Language attitude studies present the variances of shifts between languages and perceptions of identity among different speech communities.

Some other studies focus on Arabic-Turkish bilingualism and language attitudes of native ATBs' towards Arabic and Turkish, since this language variety is considered as endangered (q.v. introduction above) and needs to be documented and described in detail. Anthropologically, Cengiz (2006) remarks that there are three centers in Hatay where Arabic and Turkish are spoken by ATBs (p. 26-27). Young population prefers speaking Turkish with the effect of mass media which they are more exposed to. Educational environment is another factor which has an impact on subject-matter. Whereas young ATBs speak Arabic with elderly family members, they speak Turkish in social settings, schools and government agencies; thus resulting in a significant increase in the use of Turkish among youngsters (Cengiz, 2006: 32). Accordingly, Sofu (2009), in her study on ATB families, reports that outside factors have an effect on the language attitudes of bilingual speakers. The parents which she interviewed advice their children to keep speaking Turkish, but not to speak Arabic in community; so, to hide their Arabic identity (p. 246-251). Although some other positive indications towards Arabic identity and being bilingual were observed in these families, it is very obvious that there is a language shift between generations (Sofu, 2009, p. 256). Another recent study about ATBs in Hatay (Kocaoğlu, 2019) quantitatively sheds light on the language attitudes of this language community from a broader perspective. Kocaoğlu (2019) concludes that there is a general tendency among ATBs to respond the attitude scale negatively. They see Arabic as possessing a lower status compared to Turkish and although they consider Arabic as their mother tongue, they put a premium on this langauge only for religious purposes (p. 113-115). Similar findings are discussed in the quantitative study conducted in four districts of Mersin where the same Arabic variety is spoken by native inhabitant ATBs (Çetintaş Yıldırım, 2019, p. 82). Socially, the speakers possess very positive attitudes towards Arabic, but personally, the attitudes turn into very negative in certain conjuncture. Use of Turkish is more promoted by Mersin ATBs both socially and in intimacy and younger generations are not desired to acquire Arabic (adults mostly address them in Turkish, which generates gaps in the language transfer among generations). Spoken Arabic in Mersin can be considered as more endangered than the one in Hatay. So, comparing the results of these two language attitude studies on the same Arabic variety can reveal striking results.

\subsection{Research Questions}

This study seeks answers to the following questions.

- How do the attitudes of ATBs from Mersin and Hatay towards Arabic and Turkish affect their sense of social identity?

- How do the attitudes of ATBs from Mersin and Hatay towards Arabic and Turkish affect their language choice?

\section{Method}

This study compares some of the quantitative results of two previous studies conducted on ATBs reside in Mersin and Hatay. The results will display the differing language attitudes of these two language communities, and provide an insight about the future dynamics of these two language varieties. 


\subsection{Sample/Participants}

The participants of this study are the Arabic-Turkish speaking bilinguals who reside in the cities of Mersin and Hatay.

\subsection{Instrument}

The data base of the study is consisted of the results obtained from two language attitudes questionnaires: Language Attitudes Scale for Arabic Spoken in Mersin (Çetintaş Yıldırım, 2019) and Language Attitudes Scale for Arabic Spoken in Hatay (Kocaoğlu, 2019). The number of participants from Mersin is 379 and from Hatay is 426 . These questionnaires are region-specific, but contain similar close-ended five-scale Likert type survey questions - the former Scale contains 31 questions and the latter Scale contains 20 questions. The Reliability Test (Cronbach's alpha) result is 0.62 for Mersin Scale and 0,60 for Hatay Scale which indicate that both scales possess medium-level degree of reliability $(0.30$ $<\mathrm{a}<0.69$ ) (Büyüköztürk, 2016, p. 109). Both scales used nonparametric statistical analyses (MannWhitney U Test) and concentrated on significant differences between demographic variables. Arithmetic mean of each question was used to comment on the attitudinal dispositions of ATBs on different sub-concepts. 11 sets of questions from both scales which measure the same judgement and signify the same orientation are going to be taken into consideration in the current study, and the results of these questions are going to be compared 1 and 2 is evaluated as a negative response, 3 as irresolute and 4 and 5 as a positive response.

\subsection{Data collection procedure}

As mentioned in the previous section, the analysis of this study is based on the quantitative results of questionnaires which have already been applied to ATBs in Mersin and Hatay. 11 questions from both questionnaires are identified as having equal contents; for instance, one set is consisted of two questions, each of which are taken from one scale and which measure attitudes on language-cultural identity relationship and instructional language use or on transmission of languages between generations. Two main themes, the cultural/social identities (how language attitudes of ATBs are related to their sense of identity) and language choices (between Arabic and Turkish) of participants will be covered. So, four sets of questions query attitudes of ATBs about their rate of Arabic-Turkish use and their sense of belonging to a cultural/social identity. Seven sets query attitudes about language choices of ATBs: which language is preferred under what circumstance. The questions are going to be stated and reviewed in the further sections of this study.

\subsection{Data analysis}

The scope of the recent research covers detecting the shared knowledge, perceptions and meanings ascribed to Arabic and Turkish by ATBs. The findings, then, will present insights about the main themes stated above. From this aspect, Phenomology is employed as the main research design (Yildirım and Şimşek, 2018, p. 69). The quantitative results (arithmetic means of each ATB groups for every question) will be discussed under the stated themes. 


\section{Results}

\subsection{First Theme: Sense of Belonging to A Cultural/Ethnic Identity}

This theme includes the findings about the relationship between language use and the sense of identity. Four sets of questions from the two scales are going to be compared. The sets are specified below.

First set:

- Mersin ATBs (MATBs): I consubstantiate speaking Arabic with ignorance.

- Hatay ATBs (HATBs): Using Arabic words in a conversation held in Turkish is a sign of ignorance.

Second set:

- MATBs: I think that Arabic is not a part of my identity.

- HATBs: My native language is Arabic.

Third set:

- MATBs: I think that speaking Arabic is a shame.

- HATBs: Speaking Arabic makes me feel esteemed.

Fourth set:

- MATBs: I like speaking Arabic in my immediate environment.

- HATBs: I ensure a sincere conversation when I speak Arabic in my environment.

The results for these four sets of questions are given in table 1 (S represents 'set' in the table).

Table 1. The results for the first theme

\begin{tabular}{lll}
\hline & Means / Std. Deviations \\
\hline Set Number & MATBs & HATBs \\
\hline S1 & $4.31 / 1.12$ & $3.98 / 1.32$ \\
S2 & $2.22 / 1.16$ & $4.28 / 1.06$ \\
S3 & $4.41 / 4.41$ & $2.95 / 1.27$ \\
S4 & $3.66 / 3.66$ & $3.45 / 1.16$ \\
\hline
\end{tabular}

For S1, the mean of MATBs reveal that their attitude towards Arabic is more negative than the attitude of HATBs. HATBs are irresolute about matching Arabic speaking with ignorance. MATB mean can be interpreted as this group considers Arabic as a part of their identity and think positively about Arabic language for S2. Similarly, HATB group internalizes Arabic as their native language. S3 reveals that both MATBs and HATBs evaluate Arabic negatively. HATBs are close to being irresolute but MATBs relate speaking Arabic with ignorance. It can be concluded that both groups are irresolute for speaking Arabic in their environment when the results of S4 is considered. The overall results indicate that both MATBs and HATBs hold negative attitudes towards Arabic language, resulting in a promotion to Turkish language in their self identity. 


\subsection{Second Theme: Language Choice between Arabic and Turkish}

This second theme deals with the choice of MATBs and HATBs among Arabic and Turkish languages. Language choices can give a clue about the future shifts from one language to another. Seven sets of questions from the two scales are going to be compared in this section. The sets are as stated below.

First set:

- MATBs: I think that Turkish is a more effective language than Arabic.

- HATBs: Arabic is more important than Turkish.

Second set:

- MATBs: I think that Arabic is an instructional language just as Turkish.

- HATBs: If children had been taught in Arabic language, they would have been more successful.

Third set:

- MATBs: Our children should acquire Arabic before Turkish.

- HATBs: It is enough for our children to acquire only Turkish language.

Fourth set:

- MATBs: I think that speaking Arabic affects my professional life in a negative way.

- HATBs: Speaking Turkish fluently is important for my professional life.

Fifth set:

- MATBs: I believe that speaking Arabic provides benefits to me under different circumstances.

- HATBs: Speaking both Arabic and Turkish provide benefits.

Sixth set:

- MATBs: I try to hide my Arabic accent in Turkish speaking communities.

- HATBs: People who speak Turkish with Arabic accent have difficulty in finding a job.

Seventh set:

- MATBs: It is necessary not to speak Arabic in a conversation hold in Turkish.

- HATBs: I speak Turkish with an educated person.

Table 2 gives the results for the second sets of questions. For the first set of questions, MATBs are irresolute, which indicates that both Arabic and Turkish are effective languages in their daily lives. HATBs are negative; they think that Arabic does not hold a significant importance over Turkish. Second set yields results to the detriment of Arabic: For both groups, Arabic is not considered as an instructional language. According to the results of the third set, MATBs prefer Turkish to be acquired before Arabic but HATBs want their children to acquire both languages. Acquiring only Turkish is not enough for them. The fourth set, which measures the attitudes from the perspective of language use in professional life, produces contrary results. While performing their professions, Arabic is important and useful for MATBs and similarly, fluent Turkish use is not so important for HATBs, either. The proficient use of both languages is equally substantial for both groups according to the means obtained in set five. Especially HATB participants think that using Arabic and Turkish jointly can provide benefits for them. MATBs are more irresolute about this matter. When the results of the sixth set are inspected, it is seen that HATBs are more tolerable about their Arabic accented Turkish speech. MATBs are undecided between trying to hide or not to hide their Arabic accent. The last set reveals that MATBs prefer speaking 
Turkish more than HATBs in conversations held in Turkish. They are irresolute about speaking Arabic in such conversational environments. HATBs, on the other hand, are more positive towards Arabic. The results of all sets indicate that the attitudes towards Turkish language are more positive.

Table 2. The results for the second theme

\begin{tabular}{lll}
\hline & Means / Std. Deviations \\
\hline Set Number & MATBs & HATBs \\
\hline S1 & $3.59 / 1.08$ & $2.71 / 1.26$ \\
S2 & $3.24 / 1.36$ & $2.26 / 1.05$ \\
S3 & $2.15 / 1.16$ & $3.80 / 1.12$ \\
S4 & $4.19 / 0.94$ & $2.09 / 0.96$ \\
S5 & $3.57 / 1.42$ & $4.62 / 0.56$ \\
S6 & $3.63 / 1.27$ & $2.85 / 1.20$ \\
S7 & $3.15 / 1.41$ & $2.76 / 1.31$ \\
\hline
\end{tabular}

\section{Discussion}

Two findings can be deduced from the results of the study presented in the previous sections. The first finding provides inferences about ATBs' attitudes containing the sense of belonging to a social/cultural identity. With the exception of the third question, MATBs' responses are negative and on the detriment of Arabic language. They consider Arabic as a part of their personal identity but they identify speaking Arabic with ignorance and report that speaking Arabic means disgrace. They are not sure whether or not speaking Arabic with other ATBs is a favorable activity. When compared to MATBs, HATBs are more irresolute, but not negative, in their attitudes towards Arabic. They regard Arabic language as their native language and do not consider speaking it as a sign of ignorance. Having Arabic conversations in their social environment does not have an effect on interpersonal sincerity. The only negativity of the participants is observed for the third question, in that HATBs do not feel themselves privileged for speaking Arabic. When the attitudes of the two groups are compared, it can be concluded that HATBs regard Arabic as a part of their ethnic and social identity more than MATBs. The reflection of overall negative attitudinal behavior of MATBs towards Arabic can also be monitored from their language choices. HATBs are more depended upon the Arabic identity than MATBs. This finding about MATBs is in accordance with the emphasis of Büyükkantarcioğlu (2006); positive or negative, all attitudes towards a language can shed a light on how the members of a language community perceive their sense of identity (p. 62). The second finding gives implications about the language choices of the groups. Assigning a positive value to Arabic language is important for the transfer of this language to new generations and its circumstance in the future. Arabic language is under the effect of a more dominant official language (Turkish), so any negative attitude towards it will pretty much affect its use. As Çetinkaya (2017) emphasizes, minority languages are considered as being in a lower status than majority languages (p. 375). With the effect of this situation, individuals belonging to minority communities may minimize the use of their native languages or even refuse their own ethnic identity. As a consequence of that, Arabic use can be hindered by the dominancy of the official Turkish language. The result that MATBs are more negative when their attitudes are compared to the HATBs' can be interpreted as a future endangerment towards Mersin Arabic variety. Although MATBs think that both 
Turkish and Arabic have equiponderant importance in their lives, they do not think that Arabic is an instructional language like Turkish. On the one hand, they want their children to acquire Arabic language first, it is not a problem for them to speak Turkish with Arabic accent and speaking Arabic in a Turkish speaking community is not something odd. On the other hand, MATBs respond that Arabic does not bring practical advantages for their professional life. This is an indication of the value of Arabic for MATBs: Arabic is the language of daily conversations but it has got no use for a professional career and official affairs. So, MATBs consider that they do not need this language for survival, and minimize its use. Distinctly from MATBs, HATBs see both languages as having equal importance, want their children to acquire both Arabic and Turkish, does not mind speaking accented Turkish and believe that using Arabic in their professional career may bring benefits. The only negative attitude is about the use of Arabic as an instructional language; HATBs think that Turkish is enough for their children to have the necessary education. The results obtained from the answers of HATBs reveal that Arabic has the potential to be transferred from one generation to another in Hatay, which is in a contradiction of the results obtained from the answers of MATBs.

\section{Conclusions}

Language choices and relating language attitudes to social/cultural identity can dramatically affect the future transmission of a language. Furthermore, if that local minority language is under the dominancy of another official language, its extinction may be the matter of fact. At this point, how densely the language community experience the sense of belonging to a social/cultural identity has a clear effect on the transfer of that particular variety. This research brought about results that HATBs feel themselves belonging to Arabic ethnic identity more than MATBs. They see Arabic as an inseparable part of their selves; therefore, they are more willing to transfer Arabic language to new generations. HATBs promote simultaneous use of both Arabic and Turkish in their professions when compared with MATBs. The conclusions about the language choices of both groups (HATBs prefer using Arabic more than MATBs) reveal that the Arabic variety spoken in Mersin is more endangered than the variety spoken in Hatay.

\section{Ethics Committee Approval}

The author(s) confirm(s) that the study does not need ethics committee approval according to the research integrity rules in their country (Date of Confirmation: June 18, 2020).

\section{Acknowledgements}

I want to express my deepest gratitude to Gülsen KOCAOĞLU, who shared her findings with great goodness and gave me the permission for using them in this comparative study.

\section{References}

Agheyisi, R. \& Fishman, J. A. (1970). Language Attitudes Studies: A Brief Survey of Methodological Approaches, Anthropological Linguistics, 12(5), 137-157.

Andrews, P. A. (1989). Ethnic Groups in the Republic of Turkey. Weisbaden: Verlag. 
Antonova Ünlü, E., Sağın Şimşek, Ç., Ateşman, E. \& Lozovska, A. (2015). Russian Immigrant Diaspora in Turkey: Language Use, Preference and Attitudes, Turkish Studies, 16(3), 391-410. https://doi.org/10.1080/14683849.2015.1067864

Antonova-Ünlü, E., Sağın Şimşek, Ç. \& Kavanoz, S. (2016). Türkiye'de Yaşayan İngiliz Kökenli Göçmenlerin Dil Kullanım, Tercih ve Tutumları, YILDIZ Journal of Educational Research, 1(1), 56-76.

Atsız Gökdăg, B. (2011). Doğu Karadeniz'de Konuşulan Diller ve Türkçe ile Etkileşimleri, Karadeniz Araştırmaları, 31, 111-134.

Bangeni, B. \& Kapp, R. (2007). Shifting Language Attitudes in Linguistically Diverse Learning Environment in South Africa, Journal of Multilingual and Multicultural Development, 28(4), 253269. https://doi.org/10.2167/jmmd495.0

Büyükkantarcıoğlu, S. N. (2006). Toplumsal Gerçeklik ve Dil. İstanbul: Multilingual.

Büyüköztürk, Ş., Kılıç Çakmak, E., Akgün, Ö. E., Karadeniz, Ş. \& Demirel, F. (2016). Bilimsel Araştırma Yöntemleri. Ankara: Pegem.

Cargile, A. C. \& Giles, H. (1997). Understanding Language Attitudes: Exploring Listener Affect and Identity, Language and Communication, 17 (3), 195-217.

Cengiz, A. K. (2006). Dil-Kültür İlişkisi Açısından Hatay'da İkidillilik (Unpublished Master's Thesis) Mustafa Kemal University, Hatay

Choi, J. K. (2003). Language Attitudes and The Future of Bilingualism: The Case of Paraguay. International Journal of Bilingual Education and Bilingualism, 6(2), 81-94. https://doi.org/10.1080/13670050308667774

Çetinkaya, S. (2017). Çokdillilik ve Kimlik. The Journal of International Social Research, 10(50), 371377.

Çetintaş Yıldırım, F. (2019). The Language Attitudes of Mersin Arabs in Turkey: Scrutinizing from Five Different Perspectives. In Kara, Ö. T. and Ulum, Ö. G. (Eds.). Language and Literature II, (pp.59-85). Ankara: Akademisyen.

Edwards, J. (1999). Refining Our Understanding of Language Attitudes. Journal of Language and Social Psychology, 18(1), 101-110.

Gawronski, B. (2007). Attitudes Can Be Measured! But What Is an Attitude? Social Cognition, 25(5), 573-581.

Karahan, F. (2005). Bilingualism in Turkey. Cohen, J. et al (Eds.). Proceedings of the $4^{\text {th }}$ International Symposium on Bilingualism, 1152-1166. Somerville, MA: Cascadilla.

KONDA (2017). Biz Kimiz? Toplumsal Yapı Araştırması. [PDF File] Retrieved from http://www.Konda.com.tr/wp-content/uploads/2017/02/2006_09_KONDA_Toplumsal_Yapi.pdf

Kocaoğlu, G. (2019). Language Attitudes of Arabic-Turkish Bilingual Speakers in Hatay Towards Arabic and Turkish. Unpublished Master's Thesis. Mersin University Institute of Social Sciences: Mersin.

Liebscher, G. \& Dailey-O'Cain, J. (2009). Language Attitudes in Interaction, Journal of Sociolinguistics, 13(2), 195-222. 
Sofu, H. (2009). Language Shift or Maintenance within Three Generations: Examples from Three Turkish-Arabic-Speaking Families, International Journal of Multilingualism, 6(3), 246257.https://doi.org/10.1080/14790710902878684

Thisaphungo Mukhuba, T. (2005). Bilingualism, Language Attitudes, Language Policy and Language Planning: A Sociolinguistic Perspective, Journal of Language and Learning, 3(2), 268-278.

Weisman, E. M. (2001). Bicultural Identity and Language Attitudes: Perspectives of Four Latina Teachers, Urban Education, 36(2), 203-225.

Yalınkılıç, K. \& Yağmur, K. (2014). Batı Trakya Türklerinin Anadillerine ve Kültürlerine Karş1 Tutumlar1, Bilig, 70, 283-306.

Yıldırım, A. and Şimşek, H. (2018). Sosyal Bilimlerde Nitel Araştırma Yöntemleri. Ankara: Seçkin.

\title{
Dil seçimi ve kimlik: İki ayrı beldedeki dil tutumlarının karşılaştırılmasına
}

\author{
dayanan bir araştırma
}

\section{$\ddot{O} \mathbf{z}$}

Bu çalışma, Anadolu'nun Doğu Akdeniz Bölgesinde yer alan Mersin ve Hatay şehirlerinden Arapça-Türkçe çift dillilerinin dil tutumlarını karşılaştırmaktadır. İki ayrı araştırmacı tarafından (Çetintaş Yıldırım, 2019 ve Kocaoğlu, 2019) tarafından belirtilen iki ayrı şehirde yürütülmüş olan dil tutumları çalışmalarının nicel sonuçları karşılaştırılmış ve Arapça-Türkçe çift dillileri evrenine genellenebilen nitel sonuçlar elde edilmiştir. İki ayrı fakat bağlantılı tema ( iki katılımcı grubunun dil seçimleri ve bir sosyal/kültürel kimliğe ait olma hissi) çalışmanın temel odağını oluşturmaktadır. Sözü edilen nicel araştırmalardan, kimlik teması için dört soru seti ve dil seçimi teması için yedi soru seti belirlenmiş ve her soru için her grubun ortalaması karşılaştııılmış ve yorumlanmıştır. Karşılaştırmalar Hatay'daki Arapça-Türkçe çift dillilerinin Mersin'deki Arapça-Türkçe çift dillilerine göre Arapçayı daha fazla içselleştirdiğini göstermektedir. İlk grup Arapçayı çalışma hayatlarında daha fazla kullanma ve yeni kuşaklara aktarma konusunda diğer gruba göre daha isteklidir.

Anahtar sözcükler: dil seçimi; sosyal/kültürel kimlik; dil tutumları; Arapça-Türkçe çift dilliliği

\section{AUTHOR BIODATA}

Master of Arts, Mersin University, English Linguistics, PhD, Ankara University, Linguistics, Asst. Prof. Dr., Mersin University, English Linguistics. 